\title{
Greece in Shelley's Laon and Cythna
}

\author{
By Lawrence Masakazu Yoneta ${ }^{*}$
}

This paper offers a close reading of the presence of Greece in Laon and Cythna (1817), Shelley's longest narrative poem and known also for the revised version The Revolt of Islam (1818). Shelley's idealisation of Greece informs crucial aspects of Laon and Cythna including description, theme and historical framework. Although the setting of the story is in modern Greece and Turkey, local colour is limited in favour of abstract representation to lend a universal character to the heroic idealism unfolding therein. Laon's conversion to the cause of liberty among the ruins of national progenitors represents a process of spiritual inheritance in which Greece figures as a place where past achievements bear contemporary political relevance. Classical Athens is situated as the first manifestation of the transcendental Spirit of Good in a Manichaean dualistic metaphysics of history. Greek antiquity forms the historical framework into which Laon's and Cythna's heroism is incorporated as one evolutionary stage of the alternate predominance of Good and Evil.

There was a general perception that Percy Bysshe Shelley's longest poem Laon and Cythna or the revised version The Revolt of Islam had not received due critical attention. ${ }^{1}$ Brien Wilkie, for example, called The Revolt the 'orphan' of Shelley criticism about a half century ago. ${ }^{2}$ Although nearly two decades had passed since Wilkie's statement, Stuart Sperry could still observe that The Revolt remained 'the most neglected' of all Shelley's major works. ${ }^{3}$ Even more recently Cian Duffy pointed out a lack of 'attention' from Shelley scholars to Laon and Cythna. ${ }^{4}$ But the critical body of work on Laon and Cythna and The Revolt has been constantly growing, encompassing topics as

\footnotetext{
*PhD Candidate, University of Bristol, UK.

${ }^{1}$ All references to Laon and Cythna are to Jack Donovan's edition in The Poems of Shelley, ed. Kelvin Everest and Geoffrey Matthews, vol. 2 (Harlow: Pearson, 2000), pp. 58-260. Although The Revolt of Islam is more familiar in criticism than the original version Laon and Cythna, this paper uses the latter text because it refers to the critical apparatus of Donovan's edition. The distinction between the two works is also not crucial to the arguments in what follows.

${ }^{2}$ Brien Wilkie, Romantic Poets and Epic Tradition (Madison: University of Wisconsin Press, 1965), p. 112.

${ }^{3}$ Stuart M. Sperry, 'The Sexual Theme in Shelley's The Revolt of Islam', Journal of English and Germanic Philology, 82 (1983), 32-49 (p. 32).

${ }^{4}$ Cian Duffy, Shelley and the Revolutionary Sublime (Cambridge: Cambridge University Press, 2005), p. 125.
} 
diverse as science, vegetarianism, feminism, politics, genre, Orientalism and sexuality. ${ }^{5}$

Little discussion has been devoted, however, to the role and centrality of Greece in the formation of Laon and Cythna. The poem was composed in the course of 1817, published in December and republished after revision as The Revolt of Islam in January 1818. The year 1817 saw Shelley develop an abiding interest in ancient Greece through intimacy with Thomas Love Peacock. In March Shelley moved into Albion House in Great Marlow, London. Peacock was a neighbour and became a frequent guest for the next twelve months, until Shelley left England for Italy in March 1818. Their relations soon developed into a mutual exchange of ideas in which the older writer and classicist, as James Notopoulos shows, 'stimulated and guided Shelley's classical reading'. 6 Given the period of the composition, it is only natural that Laon and Cythna should reflect Shelley's growing Hellenism.

Shelley sent a letter to an unidentified prospective publisher on 13 October 1817, shortly before completing Laon and Cythna. The letter contains a brief account of the poem with a specimen of the first canto. 'The scene is supposed to be laid in Constantinople and modern Greece', writes Shelley, 'but without much attempt at minute delineation of Mahometan manners'. 'Although the choice of the 'scene' may imply a certain degree of realism, the qualifying remark about the 'delineation' indicates his concern that the narrative might be taken to appeal to the taste for the Oriental tale, a genre popular since the eighteenth century. One possible recipient of the letter was Longman, who had recently published Thomas Moore's successful Oriental romance Lalla Rookh (1817). Shelley was also acquainted with Oriental tales including William Beckford's Vathek (1786), Robert Southey's Thalaba (1801), Lady Morgan's Missionary (1811) and Moore's Lalla Rookh. Nigel Leask offers a comparison of Laon and Cythna with Lalla Rookh and the Missionary, regarding Shelley's

\footnotetext{
${ }^{5}$ Here is a limited selection of recent critical commentaries on Laon and Cythna and The Revolt of Islam. For science, see Barbara Estermann, 'Attraction and Combination: The Science of Metamorphosis in Shelley's The Revolt of Islam', Studies in Romanticism, 50 (2011), 413-36. For vegetarianism, see Frederick Burwick, 'The Revolt of Islam: Vegetarian Shelley and the Narrative of Mental Pathology', Wordsworth Circle, 40 (2009), 87-93. For feminism, see William Keach, 'Cythna's Subtler Language', Studies in Romanticism, 37 (1998), 7-16. For politics, see Anahid Nersessian, 'Radical Love and Political Romance: Shelley after Jacobin Novel', English Literary History, 79 (2012), 111-34; Kyle Grimes, 'Censorship, Violence, and Political Rhetoric: The Revolt of Islam in Its Time', Keats-Shelley Journal, 43 (1994), 98-116. For genre, see David Duff, Romance and Revolution: Shelley and the Politics of Genre (Cambridge: Cambridge University Press, 1994), pp. 154-216. For Orientalism, see Paul Stock, The Shelley-Byron Circle and the Idea of Europe (New York: Palgrave Macmillan, 2010), pp. 99-115; Nigel Leask, British Romantic Writers and the East: Anxieties of Empire (Cambridge: Cambridge University Press, 1992), pp. 110-8. For sexuality, see Teddi Lynn Chichester, 'Shelley's Imaginative Transsexualism in Laon and Cythna', Keats-Shelley Journal, 45 (1996), 77-101; William A. Ulmer, Shelleyan Eros: The Rhetoric of Romantic Love (Princeton: Princeton University Press, 1990), pp. 50-77.

${ }^{6}$ James Notopoulos, The Platonism of Shelley: A Study of Platonism and the Poetic Mind (Durham, NC: Duke University Press, 1949), pp. 38-9.

${ }^{7}$ The Letters of Percy Bysshe Shelley, ed. Frederick L. Jones, vol. 1 (Oxford: Clarendon, 1964), p. 563 .
} 
work as a product of 'displaced revolutionary desire looking beyond the current condition of Europe for its fulfillment'. Although such comparisons may afford insights into Shelley's attitude towards the East, two fundamental questions will remain if one sees Laon and Cythna as an instance of the Oriental tale: why the poem lacks local colour and how this feature relates to its heroic idealism. Local colour is essential to Oriental tales; they are characterised by an unusual setting as well as by extravagant incidents and supernatural agencies. Their local colour can also be reinforced with elaborate annotation. Samuel Henley's copious notes to his English translation of Vathek are notable for their detailed account of Eastern manners, customs and beliefs, as well as of relevant history, mythology and geography. Indeed an Oriental setting and Eastern mythology, as David Duff notes, are the 'elements' that Laon and Cythna shares with Oriental romances of the time. ${ }^{9}$ But while Eastern mythology has a prominent presence in the poem (e.g., Manichean dualistic cosmology in the mysterious woman's tale in Canto I), its supposed Oriental setting in 'Constantinople and modern Greece' is obscured by the lack of local colour.

In Laon and Cythna proper place names, real or fictional, are rarely mentioned, nor do any notes accompany the main text. Constantinople, then the capital of the Ottoman Empire, is replaced with the Golden City. The epithet 'Golden' may recall various features of Constantinople such as the Golden Horn (an inlet of the Bosporus) and the Golden Gate and Golden Milestone (Byzantine monuments). But it is difficult to ascertain the association between the fictional and real (historical) cities without specification or annotation; after all, the epithet might simply derive from the City's 'myriad spires of gold' (1. 2068) in the narrative. In Canto V Laon arrives in the City at night to assist in the revolution that has already started there. Its appearance is depicted as follows:

the moon was hanging low

Over the Asian mountains, and outspread

The plain, the City, and the Camp below,

Skirted the midnight Ocean's glimmering flow,

The City's moonlit spires and myriad lamps,

Like stars in a sublunar sky did glow,

And fires blazed far amid the scattered camps,

Like springs of flame, which burst where'er swift Earthquake

stamps. (11. 1721-8)

This passage gives an elaborate account of the City's spires and lamps in the moonlight, which fuse to gleam like starlight with majesty and solemnity; on the other hand, the watch-fires of the encampment, likened to lava erupting in a violent earthquake, burn brightly and strongly as if they reflected the momentum of the revolution. However, the location of the City -- identified in

${ }^{8}$ Leask, p. 109

${ }^{9}$ Duff, p. 156. 
or near the 'plain' between the 'Ocean' and the 'Asian mountains' -- only vaguely marks somewhere near the Bosporus. The revised version of the poem carries the word 'Islam' in the title. It refers to the Muslim religion or Muslims in general, as in its only occurrence in the poem, 'Islam's creed' (1. 4095). But as Shelley himself notes in the letter above, there are few accounts of Islamic belief and practice in the narrative. The time is also not clear. It can only be inferred as contemporary from an allusion to the French Revolution in the opening lines: 'When the last hope of trampled France had failed / Like a brief dream of unremaining glory, / From visions of despair I rose' (11. 1-3). The story of Laon and Cythna looks as though it took place in some imaginary place rather than in the Greece and Turkey of Shelley's day.

If Shelley had wished to add more local colour to Laon and Cythna, he could have done so because there were materials to use for this purpose. Some descriptive accounts are based on Edward Clarke's Travels in Various Countries of Europe, Asia and Africa (1810-1823), a popular travelogue that went through several editions. One conspicuous example is the simile of Mount Athos in Canto V. After the bloodless removal of the monarch Othman, the multitude in the Golden City build the 'Altar of the Federation' (1. 2072) to commemorate their victory over tyranny (a rare clear allusion in the poem to a contemporary event, the Fête de la Fédération, which was a public occasion held in Paris to celebrate the first anniversary of the taking of the Bastille). At dawn Laon, as a leader of the revolution, visits the marble pyramid erected in one night. Its immensity is instantly recognisable to him, but an impenetrable morning mist prevents him from estimating its height. Its top becomes visible when the wind clears away the obstacle:

the morning's golden mist,

Which now the wonder-stricken breezes kissed

With their cold lips, fled, and the summit shone

Like Athos seen from Samothracia, dressed

In earliest light by vintagers. (11. 2101-5)

The Altar is compared to Athos, a mountain on the easternmost promontory of Chalcidice (a peninsula in the north-western Aegean Sea). Clarke gives the following account of the mountain in the Travels:

In the evening of our arrival at Sigeum, we had proof of the possible extent of vision in the clear atmosphere of this country, which would hardly be credited in any other. Looking towards the Archipelago, we plainly discerned Mount Athos, called by the peasants, who were with us, Agionoros, the Holy Mountain; its triple summit appearing so distinctly to the eye, that we were enabled to make a sketch of it. ${ }^{10}$

${ }^{10}$ E. D. Clarke, Travels in Various Countries of Europe, Asia, and Africa, 4th edn., vol. 3 (London: Cadell, 1817), pp. 207-8. 
A comparison of the two passages will show that the clarity of Athos's ridges in Clarke's account is adapted into a simile for that of the pyramid-like Altar's top. The angle from which the mountain is viewed is roughly equivalent; both 'Samothrace' (an island in the north-eastern Aegean Sea) and 'Sigeum' (what is now on the western coast of Asia Minor) are situated to the east of Chalcidice. The mountain's 'Holy' associations are suitable for the Altar because it is sanctified by 'female choirs' thronging its staircase (1. 2099). There is also a borrowing from Moore's Lalla Rookh. One of the two slaves of Othman who take Cythna to an undersea cave for imprisonment comes from 'Oman's coral sea' (1.2901). This expression is taken from the first line of 'The Fire-Worshippers', the third of the four interpolated poems in the Oriental romance: 'Tis moonlight over Oman's Sea.' Moore's note to the line provides geographical information: 'The Persian Gulf, sometimes so called, which separates the shores of Persia and Arabia." ${ }^{11}$ The borrowing from Moore suggests Shelley's care for exotic interest. With some notable exceptions like those above, however, local colour is limited in Laon and Cythna.

The presence of Greece seems to be deliberately made elusive. Referring to a region in the north-eastern Peloponnesus, 'Argolis' represents modern Greece in Laon and Cythna. It is the 'land' (1. 694) where Laon spent his early life with Cythna and developed an enthusiasm for liberty while seeing the nation subjugated to despotic rule by Othman. A memorandum in one of the draft notebooks indicates that Shelley read Clarke's account of Argolis in the Travels. ${ }^{12}$ But the place name 'Argolis' is mentioned only twice (in lines 676 and 1492). As Jack Donovan observes in the 'Headnote' to his edition of Laon and Cythna, '[o]n several occasions Greek place-names in the drafts have been cancelled or have not been transcribed into the copy from which the poem was printed'. ${ }^{13}$ Laon, for example, depicts mountains in the distance as he walks by the shore at night: 'in the northern Heaven, / Among the clouds near the horizon driven, / The mountains lay beneath our planet pale' (11. 751-3). In the last line 'Athos' has been replaced with 'The mountains'; Mount Athos is used elsewhere as a simile for the Altar of the Federation, as seen above. ${ }^{14}$ As a result, the description has become less specific in terms of location.

Presumably, Shelley's purpose behind abstract representation was to lend as little historical and cultural character to Laon and Cythna as possible so that the poem might embody, as the subtitle suggests, his 'Vision of the Nineteenth Century' without diminishing its universality. The 'Vision' itself is an allegorical story in which his ideas are tested through the words and deeds of characters. Critics generally agree that in Laon and Cythna Shelley attempts to convey his political and moral convictions, especially those concerning the 'beau ideal' of the French Revolution, as he puts it in a letter of 23 October

\footnotetext{
${ }^{11}$ Thomas Moore, Lalla Rookh: An Oriental Romance, 3rd edn. (London: Longman, 1817), p. 174.

${ }^{12}$ See Poems, p. 94, note to line 676.

${ }^{13}$ Jack Donovan, 'Headnote' to Laon and Cythna, in Poems, pp. 10-29 (p. 27).

${ }^{14}$ See Poems, p. 97, note to line 753.
} 
1817. ${ }^{15}$ Shelley himself says in the 'Preface' that the protagonists' struggle is designed to command sympathy for his 'doctrines of liberty and justice'. 16 The 'Vision' of heroic idealism becomes relevant to the 'Nineteenth Century' or to any other specific moment in history by analogy. It is the lack of historically and culturally specific character that broadens its scope of analogical relevance.

However, it is not coincidental that Greece is supposed to be the 'scene' of Laon and Cythna despite its elusive presence. Greece has a substantial, if not conspicuous, presence as the land where those people once flourished whose achievements have become an inexhaustible source of inspiration. Although Greece was originally conceived as contemporary, it has been stripped of its historical identity through deliberate cancellation of place names; the land has thus been generalised into a pure sphere of tradition and influence. The theme of hope develops around the destiny of Laon, Greek youth, who is inspired by the past glory of his nation and experiences a spiritual transformation in the land. The moral values involved in this theme are derived from Shelley's idealisation of Greek antiquity. Greece is the 'scene' of Laon and Cythna, then, in that the qualities of heroic idealism are associated with the past of the land. In other words, Greece figures as a moral rather than geographical setting in the poem.

In Canto II Laon wanders alone in Argolis and arrives at 'the wrecks of days departed / Far' (11. 748-9). Although the narrative affords few clues about the origins of the 'wrecks', their ruinous state and location suggest that they are remains of Laon's national progenitors -- the ancient Greeks, in Shelley's conception. Laon gradually feels awe as he is surrounded by 'broken tombs and columns riven' (1. 754). Little does he know how these 'wonders' (1.757) were worked by human hands, but he can unravel the stories behind them because

dwellings of a race of mightier men,

And monuments of less ungentle creeds

Tell their own tale to him who wisely heeds

The language which they speak. (11. 759-62)

Contemplation of monumental objects leads to an intuitive understanding of unknown stories of the past. Factually uncertain as it is, the 'tale' derived from contemplation of the 'dwellings' and 'monuments' makes no less impression on Laon than the concrete objects before his eyes. He undergoes a sudden conversion through an intuitive understanding of the past. The ancient

\footnotetext{
${ }^{15}$ Letters, p. 564. For example, Gerald McNiece argues that Laon and Cythna 'brings together Shelley's notions of revolutionary practices and his ideas of true revolutionary principles' (Shelley and the Revolutionary Idea (Cambridge, MA: Harvard University Press, 1969), p. 213). Michael Scrivener also states that Shelley 'addresses the leisure-class reformers and liberals, but does so in order to inspire them with revolutionary principles and ideals' (Radical Shelley: The Philosophical Anarchism and Utopian Thought of Percy Bysshe Shelley (Princeton: Princeton University Press, 1982), p. 120).

${ }^{16}$ 'Preface' to Laon and Cythna, ed. Jack Donovan, in Poems, pp. 30-47 (p. 32).
} 
Argolians are called 'a race of mightier men'; they are a distinctive group of people who are not just remote in time but also far greater in achievement than the present inhabitants of Argolis, who are now ruled by the tyrant of the Golden City. The nation's history is conceived in Laon's mind as a contrast of glorious past and gloomy present. This sense of difference from the ancients leads him to realise the limitless potential of man:

Such man has been, and such may yet become!

Ay, wiser, greater, gentler, even than they

Who on the fragments of yon shattered dome

Have stamped the sign of power. (11. 766-9)

In preceding stanzas Laon tells how his spirit has been nourished by 'the vital words and deeds / Of minds whom neither time nor change can tame' (11. 6812). He also laments that the nation has been 'withered up' (1.695) by 'their helpless misery blind' (1.715), which stemmed from their lack of wisdom and developed into the mutual antagonism in which 'they all pined in bondage' (1. 730). For the aspiring youth the glorious achievements of the past, and those of national progenitors in particular, are at once a source of inspiration and an object of emulation. Laon discovers among ruins a glimmer of 'Hope' (1. 777) for the restoration of autonomy to the nation -- that autonomy which the ancients once enjoyed in the same land. He is now determined to liberate the people: 'I will arise and waken / The multitude' (11. 784-5). The echo of Satan's cry to fallen angels in Milton's Paradise Lost -- 'Awake, arise, or be for ever fall'n' (1.330) -- enhances the dignity of Laon's heroic undertaking. ${ }^{17} \mathrm{He}$ envisions the spread of revolutionary movement all over the world. The eruptive imagery of 'a sulphurous hill' (1.785) describes the corrosive impact of the expected revolution as well as abruptness in its development; though the exclamation 'it must, it will -- / It may not be restrained!' (11. 788-9) may convey his sense of uncertainty about its prospects. Given that Argolis represents modern Greece, Laon's conversion among ruins dramatises a process in which Greece assumes historical and political significance as 'Freedom's desert land' (1. 791), or as a place where past achievements bear contemporary relevance for adherents to the cause of liberty.

Greece is no less inherent in the historical framework than the thematic aspect of Laon and Cythna. The entire historical framework is provided in the allegorical tale of the mysterious woman in Canto I. The significance of Canto I has been discussed especially by critics of the poem's structural integrity. Frederic Jones, for example, argues that the symbolism of Manichaean philosophy 'gives universality to the Revolution of the Golden City, making it but one incident in the unceasing and cosmic struggle of Good and Evil'. ${ }^{18}$ In the letter to a potential publisher cited above Shelley himself

\footnotetext{
${ }^{17}$ John Milton, Paradise Lost, in The Poetical Works of John Milton, ed. Helen Darbishire, vol. 1 (Oxford: Clarendon, 1952), pp. 5-281.

${ }^{18}$ Frederic L. Jones, 'Canto I of The Revolt of Islam', Keats-Shelley Journal, 9 (1960), 27-33 (p. 27).
} 
remarks that the first canto is 'very necessary to the wholeness of the work', although he tells little about the nature of this necessity. ${ }^{19}$ In fact, the mysterious woman's tale can be construed as Shelley's historiographical attempt to lend a universal significance to the achievements of the ancient Greeks as well as to the heroism of Laon and Cythna.

At the beginning of the poem the poet-speaker, standing on the peak of an aerial promontory at dawn, sees an eagle and a serpent fighting in the stormy sky. Having seen the latter fall into the sea, he descends to the seashore, where he finds a strange woman sitting on the sand. After caring for the wounded serpent, she invites the poet to a 'voyage divine and strange' (1.315), through which he is to be conducted to the Temple of the Spirit, a fane that enshrines the spirits of Laon and Cythna. During the voyage the woman plays the role of an instructor and relates to him 'a strange and awful tale' (1. 334). 'Speak not to me, but hear!', she says, 'much shalt thou learn, / Much must remain unthought, and more untold, / In the dark Future's ever-flowing urn' (11. 3435). Describing the flow of time and the uncertainty of coming events, the urn metaphor suggests that the 'tale' is not so much a fictional storytelling as a historical narrative. Her narrative centres on past events, but her lessons include the principle of historical evolution, which is applicable as much to the future as to the past and present. Like traditional cosmogonies she begins the tale with a creation myth: 'Know then, that from the depth of ages old, / Two Powers o'er mortal things dominion hold / Ruling the world with a divided lot' (11. 346-8). The 'Two Powers', also called the Spirits of Good and Evil, are the opposing forces intrinsic to the universe. They originated simultaneously with the birth of mankind and have since governed the workings of the physical universe by replicating it in their own likeness in proportion to their predominance. The moral universe, too, is ordered by the superintending Spirits. This is illustrated by the legend of the first man (11. 352-60). Here Cain's murder of Abel is radically reworked to describe the baneful effect that Evil has on one's mental state and actual deeds when its rival force loses dominance. History is equal to the metaphysical evolution of the two Spirits; as the poet-speaker finds out from the wall paintings at the Temple, it is nothing but 'A tale of passionate change, divinely taught, / Which, in their wingèd dance, unconscious Genii wrought' (11. 602-3).

Ancient Greece is assigned a central place in the dualistic metaphysics of history. It is told that the Spirit of Evil prevailed first and reigned over the world with 'Death, Decay, / Earthquake and Blight' (11. 379-80). Meanwhile, 'the new race of man went to and fro / Famished and homeless, loathed and loathing, wild, / And hating good' (11.365-7). Single and transcendental in essence, Evil manifests itself in 'many shapes' (1.362) and therefore is called by 'many names' (1.363). 'Tyranny' (1.386) and superstitious 'Faith' (1.386) are the agents of Evil that, as long as it exerts its influence, pervade human society by spreading 'Those subtle nets which snare the living and the dead' (1.387). Evil now soars 'aloft with overshadowing wings' (1.372) above the earth; the Spirit of Good transforms from a starry shape ('the Morning Star') to

${ }^{19}$ Letters, p. 563. 
'a dire Snake' (1. 369) and creeps 'among / The nations of mankind' (11. 373-4). While this event unravels the symbolic eagle-serpent combat that the poet sees at the beginning of the poem, it radically rewrites the Satanic legend in Genesis and Paradise Lost. The fall of Satan, traditionally associated with Lucifer (Morning Star), is replaced by that of Good, which turns into a snake after being defeated by Evil. On the other hand, the Spirit of Evil, representing an eagle, anticipates the Jupiter of Shelley's Prometheus Unbound (1820), a symbol of tyranny and oppression (the eagle is the messenger of the highest deity and a symbol of his authority in Roman polytheism). Soon after its initial defeat, however, the Spirit of Good regains its power and renews the battle against the opposing force. It is the ancient Greeks who embody its beneficial influence for the first time in history:

Then Greece arose, and to its bards and sages, In dream, the golden-pinioned Genii came, Even where they slept amid the night of ages, Steeping their hearts in the divinest flame, Which thy breath kindled, Power of holiest name!

And oft in cycles since, when darkness gave New weapons to thy foe, their sunlike fame Upon the combat shone. (11. 406-13)

Greek poets and philosophers receive divine inspiration from 'Genii', ministers of Good. Their artistic and intellectual achievements thus realised, along with other associated facts and events, are remembered by subsequent generations whenever they fight against the agents of Evil. Shelley probably had Athens in mind while referring to the 'bards and sages'; the city-state is mentioned elsewhere in the poem with the epithet 'glorious' (1.3588). In 'A Discourse on the Manners of the Ancients', written in August 1818 as an introduction to his translation of Plato's Banquet, he states that the 'period which intervened between the birth of Pericles and the death of Aristotle, is undoubtedly [...] the most memorable in the history of the world'. The 'period' in question is roughly between the fifth and fourth century BC, when Athens established its political and cultural ascendancy over other city-states. For Shelley classical Athens epitomises the ancient Greek civilisation. He has no hesitation in confining the significance of classical learning to 'the study of the writers of the age which preceded and immediately followed the government of Pericles'. ${ }^{20}$

The expression 'in cycles' in the lines quoted above describes the alternate predominance of Good and Evil over the universe. Shelley here adopts the convention of progress poem, exemplified by Thomas Gray's Progress of Poesy (1757). In this Pindaric ode the speaker traces the historical development of poetry -- from classical Greece through Renaissance Italy to modern

20، A Discourse on the Manners of the Ancients: Relative to the Subject of Love', in The Complete Works of Percy Bysshe Shelley, ed. Roger Ingpen and Walter E. Peck, vol. 7 (New York: Gordian, 1965), pp. 223-9 (pp. 223, 226). 
England -- and in passing tells how 'Freedom's holy flame' (1.65), together with associated virtues, pursues the track where the goddess of art and literature roves across primitive nations. ${ }^{21}$ In the mysterious woman's tale, as in Gray's poem, the course of historical events is explained in terms of metaphysical evolution. Freedom is also seen as one of the conditions for cultural development. In theory, the manifestations of the Spirits are not necessarily limited to political events. But her account presents their opposition primarily as the one between liberty and tyranny. Both physical and mental conflicts caused by their influence, or the 'strife of blood' (1. 416) in society and the 'silent war' (1.420) in the mind, are described with expressions carrying political connotations such as 'oppressors' (1.416) and 'free thoughts' (1. 417). The revolutionary story of Laon and Cythna unfolding after Canto I -from their revolt against the tyrant of the Golden City through the temporary liberation of its multitude to their sacrificial immolation and spiritual resurrection -- constitutes the latest stage in the evolution of the Spirits, representing an ascendancy of Good followed by a resurgence of Evil in the realm of metaphysics. Classical Athens, or more specifically democratic Athens, as the earliest realisation of political freedom, forms the basic historical framework into which Laon's and Cythna's heroism is incorporated as one generic instance of an eternal developmental pattern.

\footnotetext{
${ }^{21}$ Thomas Gray, The Progress of Poesy, in The Complete Poems of Thomas Gray: English, Latin and Greek, ed. H. W. Starr and J. R. Hendrickson (Oxford: Clarendon, 1966), pp. 12-7.
} 